\title{
Chapter 10 \\ The 2016 Unexpected Mid-State Louisiana Flood: With Special Focus on the Different Rescue and Recovery Responses It Engendered
}

\author{
Michelle Annette Meyer, Brant Mitchell, Shannon Van Zandt, \\ and Stuart Nolan
}

\subsection{Introduction}

When the Great Louisiana Flood occurred in August 2016, it was the worst disaster to affect the USA since Hurricane Sandy in 2012 (Yan and Flores 2016). However, it was largely overlooked by those outside of the area due to a lack of a "name" that is common to tropical storms (Scott 2016). The unprecedented amount of rain resulted damage or destruction of more than 90,000 homes (including 28,000 rental units), more than 40,000 homes without electricity, emergency sheltering of 11,699 residents, rescue of more than 28,000 people, and 13 drowning deaths during the 4-day disaster (GOHSEP 2016; Rhoden 2016; Terrell 2016). The USA saw this extreme flooding eclipsed by Hurricane Harvey and the rest of the devastating 2017 hurricane season barely a year later.

The Louisiana flooding in 2016, though quickly overshadowed, set the stage for a variety of innovations in both disaster response and recovery - making Louisiana the test bed, once again, for disaster activities, organizations, programs, and policies. In this chapter, we discuss this flood event to showcase some of the adaptation strategies Louisianans began that provide insights for addressing large-scale

\footnotetext{
M. A. Meyer ( $\square)$

Hazard Reduction and Recovery Center, Department of Landscape Architecture and Urban Planning, Texas A\&M University, College Station, TX, USA e-mail: mmeyer@arch.tamu.edu

B. Mitchell · S. Nolan

Stephenson Disaster Management Institute, Louisiana State University,

Baton Rouge, LA, USA

e-mail: bmitch9@1su.edu; snolan7@1su.edu

S. Van Zandt

Department of Landscape Architecture and Urban Planning, Texas A\&M University,

College Station, TX, USA

e-mail: svanzandt@tamu.edu
} 
flooding and disaster-related needs across the country. We review two particular innovations that grew dramatically in 2016. The first is the exponential rise of civilian, water-based rescue teams. The second is multiple efforts at affordable housing recovery, particularly for renters, which is often an overlooked aspect of overall disaster recovery.

\subsection{The Setting for a Perfect Storm}

The August flooding in southern Louisiana set numerous records for rainfall in the region and extended across 26 parishes (which are county-equivalents) (GOHSEP 2016; Di Liberto 2016). The areas in and around Greater Baton Rouge (population approximately 829,000 ) tend to have a relatively flat topography and rely on three rivers, the Amite River, the Comite River, and the Tangipahoa River, to transport excess rainwater into Lake Pontchartrain to the south. Hundreds of tributaries and bayous also drain surface water from neighborhoods to these rivers. During the first 36 hours of the rain commencing on the afternoon of 11 August 2016, the rivers quickly filled and reached major flood stage, which is summarized by the National Weather Service as potential catastrophic flooding with the possibility to harm life and property (NWS 2017). Before the event was over, four rivers (Amite, Comite, Tangipahoa, and Tickfaw rivers) shattered previously recorded high water levels by as much as 6 feet at 11 different locations (Table 10.1) (Di Liberto 2016).

Precipitation finally diminished about 2 days later. Throughout the Greater Baton Rouge and Lafayette areas, localities recorded 10-20 inches of rain over a 48-hour period (Table 10.2). Some of the hardest hit areas - North Baton Rouge neighborhoods and South Lafayette -experienced 20-30 inches of rain, while the hardest hit parish, Livingston, recorded rainfalls reaching 32 inches. According to the National Weather Service's Hydrometeorological Design Study Center, these 48-hour rain-

Table 10.1 River gauge records set during the August 2016 flood event organized by day the record was set

\begin{tabular}{l|l|l|l}
\hline Gauge & Old record (year) & New record (year) & Difference \\
\hline Comite - Olive Branch & 23.37 feet $(1961)$ & 26.96 feet $(8 / 13)$ & +3.59 feet \\
\hline Amite - Darlington & 22.05 feet $(1990)$ & 22.54 feet $(8 / 13)$ & +0.49 feet \\
\hline Amite - Magnolia & 51.91 feet $(1977)$ & 58.56 feet $(8 / 13)$ & +6.65 feet \\
\hline Tangipahoa - Amite & 24.73 feet $(2016)$ & 26.28 feet $(8 / 13)$ & +1.55 feet \\
\hline Tickfaw - Holden & 21.04 feet $(1983)$ & 22.16 feet $(8 / 13)$ & +1.12 feet \\
\hline Comite - Joor Rd & 30.99 feet $(2001)$ & 34.22 feet $(8 / 14)$ & +1.23 feet \\
\hline Amite - Denham Spring & 41.50 feet $(1983)$ & 46.20 feet $(8 / 14)$ & +4.7 feet \\
\hline Amite - Bayou Manchac & 18.85 feet $(1983)$ & 21.50 feet $(8 / 14)$ & +2.65 feet \\
\hline Tangipahoa - Robert & 27.10 feet $(1921)$ & 27.33 feet $(8 / 14)$ & +0.23 feet \\
\hline Amite - Port Vincent & 14.65 feet $(1983)$ & 17.50 feet $(8 / 15)$ & +2.85 feet \\
\hline Amite - French Settlement & 7.40 feet $(1977)$ & 9.21 feet $(8 / 16)$ & +1.81 feet \\
\hline
\end{tabular}


Table 10.2 Rainfall amounts observed over a 72-hour period (National Weather Service 2019)

\begin{tabular}{l|l}
\hline 72-hour rain totals \\
\hline Livingston & 25.5 inches \\
\hline Norwood (East Feliciana Parish) & 22.0 inches \\
\hline Zachary (East Baton Rouge Parish) & 26.1 inches \\
\hline Baker (East Baton Rouge Parish) & 21.2 inches \\
\hline
\end{tabular}

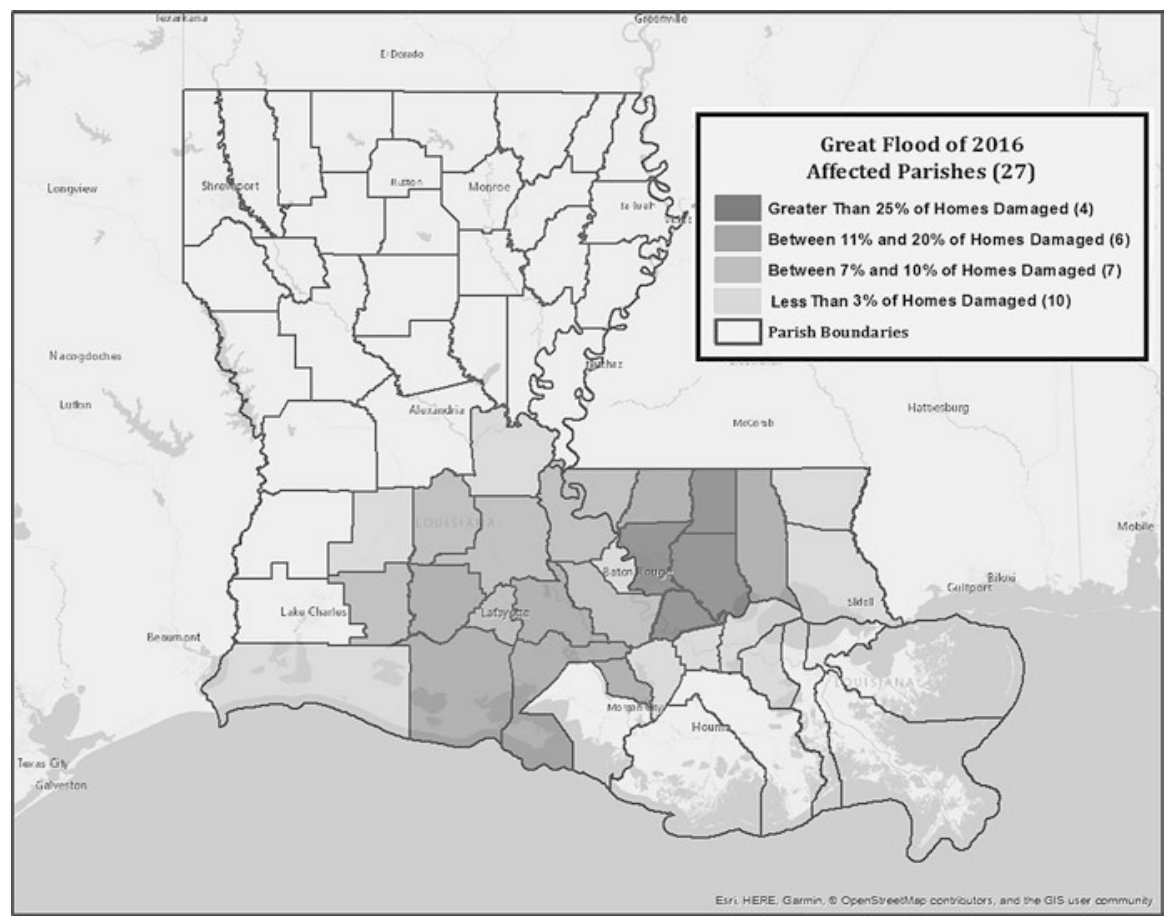

Fig. 10.1 Map of Louisiana showing the percentage of homes damaged in the 2016 floods by parish. (Adapted from the Stephenson Disaster Management Institute and Louisiana State University)

fall totals in Louisiana exceeded a 0.2\% annual probability (GOHSEP 2016). Overall, the impacted area was roughly 180 miles in length and 80 miles widespread across inland South Louisiana. Figure 10.1 shows the affected areas and the percent of homes affected in each parish.

This flooding is not unique to Louisiana. Predictions across the country with a changing climate indicate that many more inland areas will see increasing number of days with extreme rainfall (Di Liberto 2017). The Fourth National Climate Assessment (Reidmiller et al. 2017) describes increasing likelihood of extreme rainfall events across nearly the entire USA, which when coupled with decaying and damaged stormwater and flood-related infrastructure will produce higher risks of 
flooding throughout the country. Extreme rainfall in Southeast USA, specifically, is expected to double or triple the current average frequency. The total rainfall witnessed in Louisiana in the 2016 floods was barely less than the totals witnessed a year later during Hurricane Harvey, in which the highest recorded rainfall was 48 inches and many Texas coastal areas experienced between 20 and 40 inches of rain in just a few days (Di Liberto 2017).

Extreme rainfall events produce challenges for emergency management and community hazard planning. These events, in comparison to tropical coastal storms, lack the lead times for populations to evacuate or to prepare their homes for the water. Also, in comparison to riverine flooding, extreme rainfall also lacks the lead time to prepare sandbags and attempt to reduce the flood impacts. Thus, residents are often caught by surprise. This "unexpected" inland flooding from extreme rain is soon to be a regularity for many parts of the USA. Two innovations we discuss grew in response to the immediate needs and extreme damage of the 2016 Louisiana flooding - water-based rescue and rental housing recovery. These ideas provide ideas for other locations across the country that will soon also be adapting to extreme rainfall disasters.

\subsection{Response Challenges and Innovations: The Growth of Organized Civilian Rescuers}

The speed of rainfall onset and the lack of a coastal storm to warrant evacuation orders generated challenges for first responders from the state to local levels. These challenges led to emergency managers calling for help from civilians, and many civilian rescue teams answered this call. Often lumped together under the name "the Cajun Navy," this multitude of organizations and individuals operated often independently of emergency officials to rescue thousands of lives.

Response operations are normally a very centralized effort coordinated by state leaders from the State Emergency Operations Center (SEOC). At the time the precipitation began to accelerate on 11 August 2016, the Louisiana Governor's Office of Homeland Security and Emergency Preparedness (GOHSEP) had in place its Crisis Action Team consisting of members of its Operations Staff actively monitoring ongoing events as they were being reported by local officials. State and local officials began lifesaving actions as early as 06:00 Friday morning on 12 August 2016. However, due to the rapidly deteriorating conditions and the immediate nature of the requests from local officials for lifesaving equipment and personnel, the Louisiana Department of Wildlife and Fisheries agents, Louisiana National Guardsmen, Louisiana State Police troopers, and State Fire Marshal agents were immediately pressed into service to augment local first responders without the formalities of the usual memorandums of understanding or standard operating protocol for support requests (GOHSEP 2016). At the end of the day, 237 human rescues had been reported in 6 different parishes. Among the lifesaving actions taken 
this day included the full evacuation of 145 nursing home residents in the city of Denham Springs as well as the evacuation of a housing authority that included 19 individuals with access and functional needs and 11 caretakers in the city of New Iberia (GOHSEP 2016). While the exact number of people who were rescued is impossible to be determined, the State After Action Report (AAR) states that the SEOC alone coordinated the rescue of more than 15,000 people and 2200 pets with the Louisiana National Guard and their high-water vehicles responsible for the majority of those rescues.

Further recognizing the escalating need, the state called for help from civilians, a call that would foreshadow the same type of call for help by Texas jurisdictions during Hurricane Harvey (McCausland et al. 2017). The AAR acknowledged that more than 13,000 citizens were rescued by local first responders who were aided by volunteers equipped with their own flat-bottomed boats. These volunteers have since become more organized as part of a growing "Cajun Navy Movement," which includes several different nonprofit and for-profit organizations, some using the Cajun Navy moniker, who travel across the country to do water-based rescues (Meyer et al. 2018). These organizations and other civilian rescue groups have since responded to Hurricanes Harvey, Irma, and Maria in 2017 and Florence and Michael in 2018, along with other smaller-scale flooding in Texas.

Helping behavior in disasters, like that of civilian rescuers, takes a variety of forms, ranging along a continuum from spontaneous and informal efforts to more organized emergent group activity to, finally, formal organizational response (National Research Council 2006). Disaster research has long shown that survivors are most likely to be rescued and offered aid first by other survivors in close proximity (Noji 1997; Aldrich 2012; Kendra and Wachtendorf 2016). This individual or small group rescue scenario can be enlarged to emergent spontaneous groups that quickly organize to address a specific need without a formal, bureaucratic organization. They begin to perform many different types of activities quickly following a disaster impact, including providing emergency assistance, identifying and registering survivors, and engaging in cleanup and community restoration efforts (Forrest 1978; Dynes 1974). Although classic and contemporary scholarship has described spontaneous volunteer behavior in disaster settings (e.g., Barton 1969; Fritz 1961; Steffen and Fothergill 2009) as well as formal and informal organizational response (e.g., Dynes 1974; Kendra and Wachtendorf 2003; Aguirre et al. 1995; Clarke and Short 1993; Perry and Lindell 2003), as Tierney et al. (2001: 113) noted, "we know relatively little about spontaneous volunteers and even less about the other patterns of volunteer behavior" such as loosely organized, volunteer rescue efforts like that which occurred in 2016 and since.

The "Cajun Navy" is the popular moniker of outdoorsmen (and women) who began as groups of civilians mostly from southern Louisiana who used their personal flat-bottomed boats to conduct volunteer rescues. Some of these groups claim origins during Hurricane Katrina, while others began or diverged during the Baton Rouge floods in 2016 and then in storms in 2017 and 2018 (Ancelet et al. 2013). While neighbor-to-neighbor rescues during disasters are not uncommon, the Cajun 
Navy Movement has quickly grown from emergent spontaneous response to an extending network of more or less structured organizations that coordinate both established and spontaneous volunteers during emergency rescue and response. These groups claim origins in Hurricane Katrina where they boated through New Orleans calling out for those in need of rescue. With the growth of social media giants Facebook and Twitter and the introduction of Zello (the walkie-talkie, twoway communication application for smartphones, zello.com), these groups were able to change their rescue tactics during the 2016 flooding to identify those in need of rescue and then coordinate with their members to get a volunteer to that person (Personal Interview 2018; Raja 2017).

This emergent and volunteer behavior is known to occur in all types of natural disasters, but the use of social media and the rise of smartphone applications allowed the Cajun Navy Movement to coalesce and spread, making it an innovation in civilian response but also a challenge to official emergency management practices. Emergency management commonly uses a command and control format in which an Emergency Operations Center, led by emergency managers, police, fire, and other essential government personnel, directs government and private resources (Dynes 1983; Schneider 1992; Siegel 1985). Emergency managers and their protocols follow strict lines of authority and maintain standard operating procedures and predetermined divisions of labor (Schneider 1992).

The Incident Command System (ICS) is the official model for command and control in emergency management and represents paramilitary, top-down, centralized rigid structure of authority in disaster response. There are 12 essential features that define how ICS is implemented, 2 of these essential features are accountability and dispatch/deployment. Accountability requires that all deployed resources must check in when they arrive to a disaster, and resource tracking is required by operations to ensure all known assets conducting operations are accounted for by command to avoid duplication of effort, among other concerns. In addition, dispatch/deployment explicitly states that personnel and equipment should not self-deploy to an event. Any self-deploying personnel and equipment to disaster areas may cause unintended stress on the established and formal command and control structure unless properly coordinated in advance.

In these systems, spontaneous behavior, including normal volunteer helping behavior, can be viewed as problematic and is prevented or, at minimum, controlled. The civilian rescuers represent a direct challenge to these traditional emergency management operations. Volunteers commonly self-deployed and often did not check in with local officials (Personal Interview 2017). For example, the officials in some areas of Texas refused to allow them into their communities so the boat rescuers circumvented the main entries to participate in rescues anyway. State and local lawmakers both encouraged rescue groups, via providing gasoline to support their efforts (Hilburn 2017), and also expressed concerns particularly around issues of liability and risk (Ballard 2018). This led Louisiana as a state, and local jurisdictions, to consider legal adaptations that could facilitate, coordinate, or, conversely, control these civilian efforts (Crisp 2018; Grueskin 2017). As rescue groups rise and make use of social media and new technologies, jurisdictions across 
the country will need to prepare for this coordinated influx of volunteers. And as more powerful unpredicted extreme rainfall storms increase in number, the challenges will have even more of an urgency to be addressed.

\subsection{Housing Recovery Challenges and Policy Innovations}

After rescuing ended and civilian and formal emergency responders returned home, residents across the state began the usually long recovery process. Gutted but unrepaired homes abutted properties with FEMA trailers and repairs underway throughout parts of East Baton Rouge Parish in December 2017, roughly 16 months following the flood. Other parts of the parish looked as though a 500-year flood event never happened, with homes completely rebuilt. Recovery, especially housing recovery, is the most understudied and misunderstood stage of a disaster (Rubin 2009). Recovery is uneven across neighborhoods and within neighborhoods, which may seem random, but research shows some predictable patterns (Hamideh and Rongerude 2018; Pais and Elliott 2008; Phillips et al. 2010). Affordable housing especially affordable rental housing (that which costs no more than $30 \%$ of a household's income, including utilities (HUD 2018)) is often damaged the most during disasters, making existing affordable housing crises much worse (Tulane School of Architecture 2007). Yet, little research or recovery programs address housing affordability issues or housing tenure after floods (Lee and Zandt 2018).

Hurricane Katrina showed that social stratification across class and race greatly affected return and recovery of housing. Those who returned to their previous homes the soonest following Hurricane Katrina were predominantly white, older, better educated, and homeowners and sustained less damage to their property compared to those who were displaced for longer periods of time or permanently displaced (Fussell et al. 2010). Even with equivalent amounts of housing damage, wealthier individuals, especially homeowners with insurance, returned more quickly. Higher socioeconomic status entails the financial resources to rebuild and also the cultural knowledge to maneuver the complicated US disaster aid process and political and symbolic capital to garner rebuilding assistance (Finch et al. 2010).

These disparate housing recovery outcomes from Hurricane Katrina are not unique. Social vulnerability to disasters describes how "social inequalities and historic patterns of social relations" generate differential disaster impacts and recovery trajectories (Phillips and Fordham 2010, p. 4). When disaster impacts are filtered through the US social structure of race, class, gender, nationality, and disability, for example, they create "multiple and highly unequal processes of resettlement" (Fussell and Elliott 2009, p. 389). Evidence from numerous disasters across the US and the world shows that social vulnerability affects population return and housing recovery following disasters (Thomas et al. 2013; Peacock et al. 1997, 2014; Van Zandt et al. 2012).

Social vulnerability highlights how preexisting inequalities and existing social patterns, such as the current housing affordability crisis and declining 
Table 10.3 Housing types before the flood (American Community Survey 2016, 5-year estimates) ${ }^{a}$

\begin{tabular}{|c|c|c|c|c|c|}
\hline & $\begin{array}{l}\text { Total housing } \\
\text { units }\end{array}$ & $\begin{array}{l}\text { Percent } \\
\text { single-family } \\
\text { detached units }\end{array}$ & $\begin{array}{l}\text { Percent boat/ } \\
\text { RV/van units }\end{array}$ & $\begin{array}{l}\text { Percent } \\
\text { multifamily } \\
\text { units }\end{array}$ & $\begin{array}{l}\text { Percent } \\
\text { mobile } \\
\text { homes }\end{array}$ \\
\hline United States & $134,054,899$ & 61.6 & 0.1 & 32.0 & 6.3 \\
\hline All 22 parishes & 775,544 & 69.1 & 0.2 & 10.2 & 20.5 \\
\hline Acadia Parish & 25,867 & 73.4 & 0.2 & 8.0 & 18.3 \\
\hline Ascension Parish & 44,127 & 72.1 & 0.4 & 7.2 & 20.4 \\
\hline $\begin{array}{l}\text { East Baton Rouge } \\
\text { Parish }\end{array}$ & 191,397 & 63.6 & 0 & 33.3 & 3.1 \\
\hline $\begin{array}{l}\text { East Feliciana } \\
\text { Parish }\end{array}$ & 8177 & 67.8 & 0.1 & 4.0 & 28.1 \\
\hline Iberia Parish & 30,077 & 66.4 & 0.1 & 11.3 & 22.2 \\
\hline Iberville Parish & 13,009 & 71.3 & 0.7 & 7.7 & 20.3 \\
\hline $\begin{array}{l}\text { Jefferson Davis } \\
\text { Parish }\end{array}$ & 13,596 & 75.3 & 0 & 6.8 & 17.9 \\
\hline Lafayette Parish & 97,847 & 65 & 0.1 & 23.8 & 11.1 \\
\hline Livingston Parish & 53,673 & 66.3 & 0.4 & 7.0 & 26.3 \\
\hline $\begin{array}{l}\text { Pointe Coupee } \\
\text { Parish }\end{array}$ & 11,298 & 72 & 0.1 & 6.1 & 21.7 \\
\hline St. Helena Parish & 5157 & 58.3 & 0 & 3.6 & 38.1 \\
\hline St. James Parish & 8702 & 75.4 & 0 & 9.0 & 15.6 \\
\hline St. Landry Parish & 36,172 & 68.9 & 0.1 & 9.3 & 21.7 \\
\hline St. Martin Parish & 22,536 & 66.3 & 0.2 & 6.3 & 27.2 \\
\hline $\begin{array}{l}\text { St. Tammany } \\
\text { Parish }\end{array}$ & 98,916 & 77.8 & 0.1 & 14.2 & 7.8 \\
\hline $\begin{array}{l}\text { Tangipahoa } \\
\text { Parish }\end{array}$ & 52,513 & 62.1 & 0.1 & 15.6 & 22.2 \\
\hline Vermilion Parish & 25,869 & 71 & 0.6 & 6.2 & 22.2 \\
\hline $\begin{array}{l}\text { Washington } \\
\text { Parish }\end{array}$ & 21,284 & 70.4 & 0.2 & 5.7 & 23.7 \\
\hline $\begin{array}{l}\text { West Baton } \\
\text { Rouge Parish }\end{array}$ & 10,078 & 70.5 & 0 & 9.0 & 20.6 \\
\hline $\begin{array}{l}\text { West Feliciana } \\
\text { Parish }\end{array}$ & 5249 & 69 & 0.2 & 9.5 & 21.3 \\
\hline
\end{tabular}

${ }^{\mathrm{a} B o l d}$ italics indicate greater than US value

homeownership rates, create disparate disaster effects across population groups. The population that often recovers the quickest from disasters - homeowners with insurance - is declining nationwide. The Great Recession starting in 2008 began a decline in US homeownership to a 50-year low (Rohe 2017). Consequently, renting is rising across all income groups, to nearly $40 \%$ of the US population (Table 10.3). The corresponding increase in renters quickly outpaced the amount of available rental housing and drove up rental costs. In 2011, for example, there was a shortfall of 4.8 million rental units that would be affordable to persons making less than about $\$ 19,000$ (Fernald 2013). Recent analysis by Freddie Mac (a federal mortgage agency) shows that newly constructed rental units, for example, are serving a 
greater proportion of higher-income renters than they were in 2010 (Freddie Mac 2017), even though nearly half of all current renters make less than $\$ 30,000$ a year (Fernald 2013).

The affordable housing crisis is worsened by disasters in several ways. First, affordable housing, both owned and rented, often receives the most damage in disasters because it is usually located in more hazardous areas, such as floodplains, is of lower quality that doesn't withstand disaster impacts, and often lacks the mitigation upgrades to prevent disaster damage (Fothergill and Peek 2004; Peacock et al. 2018). Housing that is affordable to the lowest-income renters, furthermore, is often more than 50 years old and more likely to be of inadequate quality according to today's building standards (Fernald 2013).

Second, tenants and landlords alike have fewer incentives to undertake mitigation that would prevent disaster damage (Burby et al. 2003). Renters are dependent upon their landlords' permission to reoccupy their previous housing, which heightens the risk of displacement (McCarthy et al. 2001; Burby et al. 2003; Morrow 1999; Fussell and Harris, 2014). Landlords may not rebuild or may rebuild their properties to higher market rates (Comerio 1998). Zhang and Peacock (2009) and Peacock et al. (2014) found that rental housing came back the slowest following Hurricanes Andrew in Florida (1992) and Ike in Texas (2008).

Third, rental rates and housing costs rise due to reduced supply of affordable housing. In Baton Rouge, for example, fair market rent for a one-bedroom apartment increased from \$728 to \$789 between 2016 and 2018 (Grueskin 2018a; Grueskin 2018b). Disasters ignite "recovery machines" in which pro-economic growth coalitions take advantage of recovery funding to rebuild neighborhoods with higher priced housing and amenities. These efforts make it more difficult for lower-income survivors to acquire post-disaster housing (Elliott and Pais 2010; Gotham and Greenberg 2014). Political will and local funding to support fair and affordable housing and counter the recovery machine are often lacking (Weil 2009). Galveston, Texas, following Hurricane Ike, and New Orleans, following Hurricane Katrina, both made changes to their public housing structures and availability, which significantly reduced the number of affordable units (Tulane School of Architecture 2007; Walters 2018). Four large housing projects in New Orleans, for example, were replaced by mixed-income housing therefore reducing the number of fully subsidized units (Henrici et al. 2010). Evidence from longitudinal research following Hurricane Katrina showed that low-income African American mothers living in subsidized public housing were the least likely to return to their same housing, followed by renters (Fussell and Harris 2014). In East Baton Rouge Parish, 753 families using Section 8 public housing vouchers were flooded in the August 2016 floods. About $42 \%$ of those were unable to locate another unit to use their voucher in the 6 months after the flood (Jones 2017). Renters, beyond having lower income on average, also are less likely than homeowners to have various financial investments, such as retirement accounts, life insurance, stocks, certificates of deposit, or savings bonds that can be useful in crises to fund new housing options (Fernald 2013).

Fourth, and importantly, recovery programs through the government or nonprofits are overwhelmingly targeted at owner-occupied housing (Comerio 1997; GAO 2010). Louisiana, for example, allowed eligible homeowners of any income level to 
receive $100 \%$ reimbursement for repairs, providing an additional $\$ 110$ million to homeowners from their Community Development Block Grant - Disaster Recovery (CDBG-DR) provided by the US Department of Housing and Urban Development (HUD) (Grueskin 2018b). Nonprofits that also address recovery housing often limit their programs to homeowners. For example, the Housing First Alliance of the Capital Area is a collaboration of about 30 local nonprofits that formed following the 2016 Louisiana Floods to address housing issues. They concentrated on restoring single-family homes first (Gallo 2017a; Gallo 2017b). Case studies have shown that governments lack clear policy strategies to address renters or rental housing issues in contrast to homeowner programs, and rental programs implemented are often ad hoc (Mukherji 2015). Government options attempted include rental subsidies or vouchers to renters to find their own housing elsewhere, temporary housing, subsidized public housing, economic incentives to rental property owners to rebuild, and homeownership programs. All these programs are often slow to begin following disaster. The "Road Home" program following Hurricane Katrina that supported owners of rental property to rebuild began 2 years after the disaster (GAO 2010). Some programs even have unintended (or intended) consequences of spatially isolating low-income populations from others, as occurred in Japan following the 1995 earthquake (Hirayama 2000), or increasing racial and economic segregation, such as following Hurricane Katrina. Furthermore, these programs often do not address the long-term, exacerbated issue of the lack of affordable housing. As noted by Gotham (2008), many market-centered recovery programs lack coherency and sustainability and may intensify existing housing issues.

Providing or developing affordable housing, especially rental housing, is a growing post-disaster challenge for jurisdictions large and small across the country. This housing issue corresponds with a variety of other social differences that lead to heightened vulnerability to disaster (Lee and Zandt 2018). Renters, for example, are more likely than owners to be younger, unmarried, and racial minorities (due in part to discriminatory mortgage lending practices) and have lower overall incomes. Renters also are less likely to have social capital connections important to disaster recovery, have lower place attachment, and, importantly, are less politically engaged to demand attention to post-disaster needs (Aldrich and Meyer 2015; Lee and Zandt 2018).

Louisiana attempted new and expanded options following the 2016 floods to address the affordable housing concerns, including rentals. State officials specifically developed programs to address affordable housing, targeting rental housing and manufactured homes. To understand the need for affordable housing, Table 10.3 depicts total housing units and housing types for the US and for the 22 parishes that received individual assistance from FEMA (i.e., locations where households could apply for direct support from FEMA for housing). These parishes had higher percentages than the US average of single-family detached homes, mobile homes, and boat/RV/van housing. Nine of the 22 parishes receiving individual assistance from FEMA had higher rates of nontraditional housing such as boat, RV, or vans than the national rate. Multifamily units are less common in these parishes than in the nation as a whole, except for East Baton Rouge Parish, where 1/3 of housing units were in multifamily structures. The most striking statistic is the high rates of 
mobile home occupancy in the affected parishes. All parishes except East Baton Rouge exceeded the national rate of mobile home occupancy, a common type of affordable housing that is understudied, but extremely vulnerable, in disaster. The percent of all housing that was mobile homes ranged from $3.1 \%$ in East Baton Rouge Parish to $38.1 \%$ in St. Helena Parish, with an average of $1 / 5$ of all housing in these parishes being mobile homes.

The 2016 flooding impacted over 28,000 rental households, of which 17,000 were very low income (Louisiana Office of the Governor 2016). The amount of rental housing needs across the affected parishes varied. Table 10.4 shows home ownership and housing costs compared to the US averages. Only East Baton Rouge Parish had a higher percent of renters than the US average, with $41 \%$ of the parish

Table 10.4 Home ownership and housing costs before the flood (American Community Survey 2016, 5-year estimates) ${ }^{\mathrm{a}}$

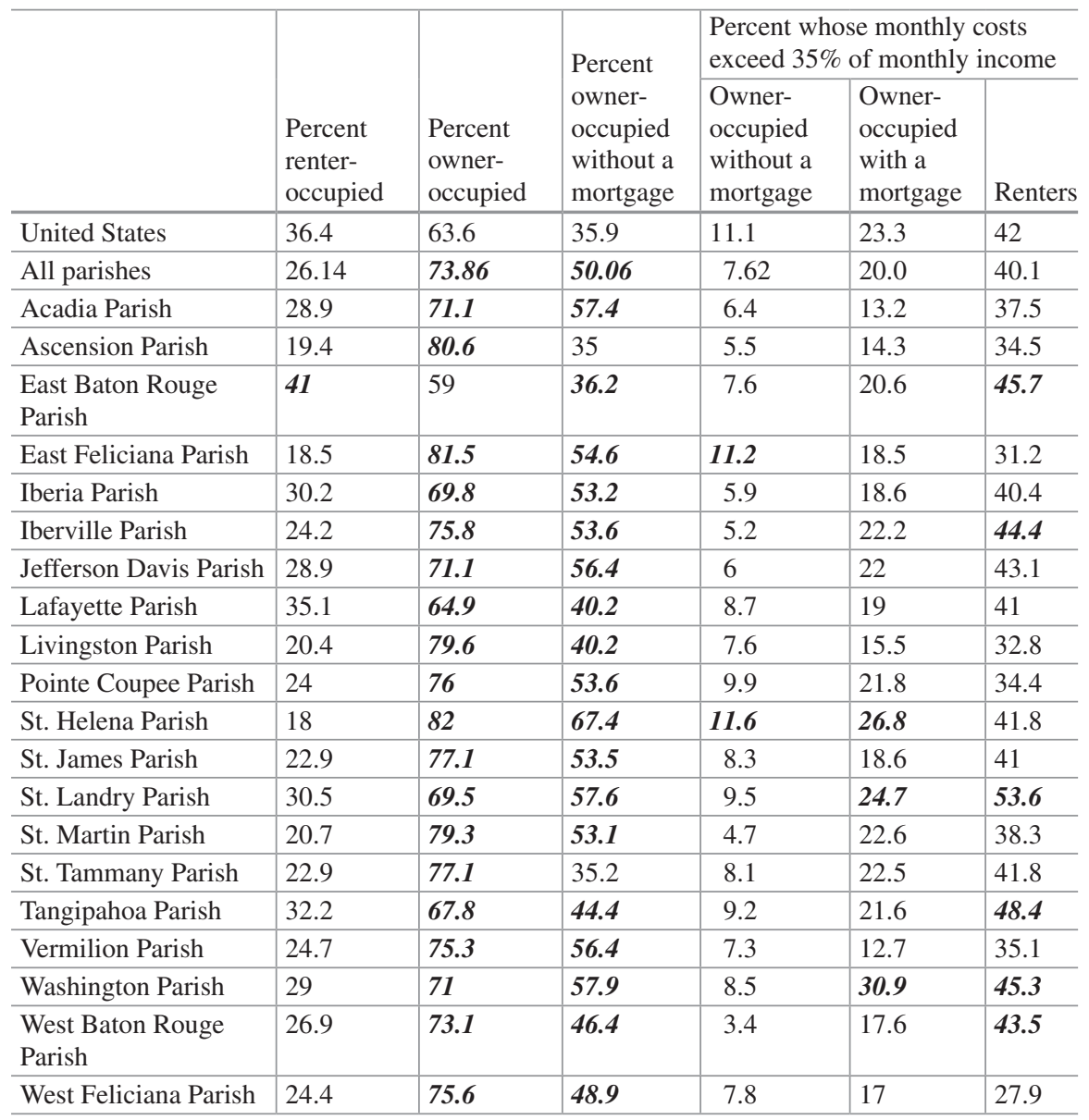

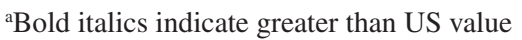


population renting their housing. Owner-occupied housing ranged from $59 \%$ in East Baton Rouge Parish to $82 \%$ in St. Helena Parish. Owning a home without a mortgage was much more common in these parishes than the US, with an average of $50 \%$ of parish homeowners living without a mortgage. Mortgages are important to understanding flood disaster recovery specifically because a mortgage requires insurance and flood insurance as a condition of the home loan if that loan is federally sponsored and located in a floodplain (FEMA 2018). Persons without a mortgage are able to let their homeowner's and flood insurance lapse, making them more at risk of being unable to rebuild on their own.

Renting is seeing a resurgence across the country across income categories, but in most parts of the country, it is still predominantly undertaken by low-income households (Fernald 2013). The affordability standard is $30 \%$ or less of income spent on housing costs (HUD 2018). Comparing housing costs across renters, homeowners with a mortgage and homeowners without a mortgage, a much larger percent of renters nationwide spend over $35 \%$ of their monthly income on housing costs (Fernald 2013). Five of the affected parishes had a higher percent of their renters with cost burdens than the national average.

The Louisiana Housing Corporation began with two programs targeted at owners of rental properties affected by the floods of 2016, which were funded through CDBG-DR from HUD. Some local governments have similar programs (Hardy 2017). Awardees for both programs must meet various affordability requirements (http://restore.la.gov/program-detailstimeline/). These programs include both loans (which may be entirely forgivable) and grants, depending on the applicant qualifications (Gallo 2017b). Landlords must qualify for the state program and have a bank that is willing to extend construction financing. The programs following Hurricane Katrina faced trouble due to the financial crisis of 2008, during which banks were unwilling to provide loans to landlords to qualify for the rebuilding support (Gallo 2017b). The state established agreements with three banks before the program began to counter some of these issues. To counter other problems experienced with the "Road Home" program following Hurricane Katrina, the flood recovery programs for the 2016 floods are run by the Louisiana Housing Corporation (a state agency created in 2011) rather than by contractors like the "Road Home" program (Gallo 2017b).

One program, the Multifamily Gap Program, offered zero-interest loan gap financing to multi-housing (at least 20 units) of both affordable and market rate housing (http://restore.la.gov/multifamily-gap-program/). The program started with $\$ 38.25$ million for developers or housing authorities (Gallo 2017b). Agencies involved in public housing or affordable housing could receive up to $\$ 40,000$ per flooded unit, and market rate rental owners could receive up to $\$ 65,000$ per flooded unit. All who accepted the funds must maintain the affordability requirements for at least 5 years after renovation. This program, as of September 2018, had distributed funds totaling \$1.5 million including two public housing authorities and two market rate complexes that were transitioning to affordable housing (Grueskin 2017).

A second program targeted landlords of smaller multifamily housing with seven or fewer units. The Neighborhood Landlord Rental Program provided financial assistance in taking out a loan for rebuild, repair, or new construction. If applicants 
comply fully, the "loan" may be completely forgiven. The program aimed to support recovery of 1,200-1,500 rental units across the state with original allocation of \$36 million (Gallo 2017a; Gallo 2017b). The program specifically required landlords to keep the properties affordable for 5 years following renovation (Gallo 2017b). Nonprofits that build affordable housing can apply to rebuild flooded housing or build new affordable housing. For-profit landlords could only apply to repair flooded housing (Gallo 2017b). This program, as of September 2018, had allocated almost $\$ 36$ million covering 340 units.

A third program was added in 2018 called The Piggyback 2018 program. The multifamily program received less interest than expected, and it was assumed to be so because large multiunit facilities may have had insurance. The five million dollars left in this program was transferred to the more popular Neighborhood Landlord Program. A larger amount (\$17.7 million) was transferred to the Piggyback program for developers who are already using low-income housing credits to build mixedincome complexes (Grueskin 2017). This program requires more than half of the development be "affordable" to those making $80 \%$ or less of the area's median income and remain at below market rate rents for 35 years (much longer than the other two programs). Five percent of the units must be affordable to those with chronic health conditions or very low incomes. It was expected to create 500 affordable units by the definition of $80 \%$ or less of the area median income. Priority goes to parishes that were flooded in 2016 and have high rent costs relative to income. East Baton Rouge Parish, which has the most rental properties of the affected parishes, meets both requirements. The Louisiana Housing Corporation had 1804 units in their tax credit-financed portfolio damaged by the August 2016 floods. Of those, about half (974) were repaired in the first 16 months of post-flood. As of September 2018, 870 units were to begin construction in early 2019.

Another program, the Baton Rouge Rebuilds Program, provides forgivable loans for repair and reconstruction of rental housing also funded by HUD. Its three main goals are (Louisiana Housing Corporation 2017):

1. Eliminate blight and stabilize neighborhoods impacted by the floods

2. Repair damaged rental housing stock that will be made available at affordable rental rates for low-income households

3. Increase the available rental stock in flood-damaged East Baton Rouge

The program is available to owners of rental property located in the city of Baton Rouge or unincorporated East Baton Rouge Parish at the time of the flood, who are in good standing with various housing programs. Priority was given to low- to moderate-income applicants who are under $120 \%$ of area median income. Oneperson households making less than $\$ 57,120$ and four-person households making less than $\$ 81,480$ would receive priority, for example. This program targets the specific types of rental housing common to the area. Site-built, modular, and manufactured housing were all eligible, a unique aspect to this program. Also, the applications were aimed for smaller rental housing developments, specifically seven or fewer units. The rental properties can be located in Special Flood Hazard Areas or not, which addresses the extreme impacts of this disaster. 
The above programs targeted owners of rental properties. As noted, these programs are slowly building or repairing some affordable housing units, many taking over 2 years to begin construction. What do renters do in the meantime? Some programs aimed to support displaced renters find or afford housing. Rebuild Livingston, for example, is a nonprofit supporting displaced renters through a Rapid Re-Housing program funded also by HUD's CDBG (Grueskin 2018a; Grueskin 2018b). The targeted population was specifically renters still living in FEMA-manufactured homes. Rebuild Livingston managed rental vouchers and case management to help those households find new rental housing. The program, though, already had a waiting list in early 2018 even as 180 renter households remained in FEMA-supplied housing. The main issue remains that there is not enough affordable housing for renters to use their rental voucher. Renters face tough decisions of taking higher cost units with the help of the voucher, but knowing that when the voucher ends in a year, they will have to move again. As of January 2018, 653 households received these vouchers, and 417 used the vouchers (Grueskin 2018a; Grueskin 2018b). By September 2018, 1217 households had applied, 151 had completed the program, and 661 were in leased housing. The rest were waiting to find affordable homes. Without affordable units, voucher programs may not be useful or may result in temporary housing of displaced low-income renters in unaffordable units.

\subsection{Moving the US Forward}

The 2016 Louisiana Floods were the worst US disaster since Hurricane Sandy in 2012. Then, they were quickly eclipsed by the more damaging Hurricanes Harvey, Irma, and Maria, along with wildfires in California. What Louisiana knows well is that changing weather patterns result in more "unexpected" events and more "worst ever" events. The intense, short-duration storms that happened in Louisiana are increasing in frequency. Their effects are occurring in areas outside of the traditional 100-year floodplains and in areas with ill-equipped drainage systems for these extremes. More flood damage has and will likely occur outside of historic floodplains given the atmospheric dynamics - thus we need more analyses of flood and rescue needs along with social vulnerability, especially housing tenure, and hazard mitigation planning in areas that may face these similar impacts.

Following the catastrophic flooding, some indicated that you cannot plan for this extreme of an event. And, furthermore, that such an unusual event should not affect the floodplain designations or building practices. FEMA actually does not change flood maps because of these less frequent events. Residents of Central Louisiana, for example, won a case against FEMA to have about 2000 homes removed from the high-risk flood zone in August 2016 just before the catastrophic flooding. A majority of those homes were underwater a few weeks later. As Central Councilman Moak quoted to the local paper, "This is an ungodly, extenuating circumstance, and I pray that it doesn't happen again, but I still believe the studies are correct; I do. They weren't arbitrarily set. They were mapped out and reapproved by FEMA" 
(Allen 2016). The city and residents, even many of those flooded in 2016, wanted to rebuild without changing their practices or increasing mitigation mechanisms. Others though continue to push for greater flood mitigation standards and innovative practices. Moving forward, disasters across the country are going to raise similar important questions about risk and planning and bring more people to the table to discuss what should be done and how do we help, including in civilian rescue and rental housing.

\section{References}

Aguirre, B. E., Wenger, D. E., Glass, T. A., Diaz-Murillo, M., \& Vigo, G. (1995). The social organization of search and rescue: evidence from the Guadalajara gasoline explosion. International Journal of Mass Emergencies and Disasters, 13(1), 67-92.

Aldrich, D. P. (2012). Building resilience: Social capital in post-disaster recovery. Chicago: University of Chicago Press.

Aldrich, D. P., \& Meyer, M. A. (2015). Social capital and community resilience. American Behavioral Scientist, 59(2), 254-269. https://doi.org/10.1177/0002764214550299.

Allen, R. (2016, September 3). Many Central homes dropped from 'high risk' zones, allowed to lose insurance weeks before flood. The Advocate. Retrieved from http://www.theadvocate.com/ baton_rouge/news/article_c6278d8e-6576-11e6-a301173b12fac153.html

American Community Survey. (2016). 2012-2016 ACS 5-year Estimates. Washington, DC: Census Bureau. Retrieved from https://www.census.gov/programs-surveys/acs/data/summaryfile.2016.html.

Ancelet, B. J., Gaudet, M., \& Lindahl, C. (2013). Second line rescue: Improvised responses to Katrina and Rita. Jackson: University Press of Mississippi.

Ballard, M. (2018, April 6). Cajun Navy, other do-gooders' rescue efforts would be regularized in bill going to Louisiana House. The Advocate. Retrieved from https://www.theadvocate.com/ baton_rouge/news/politics/legislature/article_7041d5f4-39ba11e8-ad22-d7335739f834.html

Barton, A. H. (1969). Communities in disaster: A sociological analysis of collective stress situations (Vol. 721). Garden City: Doubleday.

Burby, R. J., Steinberg, L. J., \& Basolo, V. (2003). The tenure trap: The vulnerability of renters to joint natural and technological disasters. Urban Affairs Review, 39(1), 32-58. https://doi. org/10.1177/1078087403253053.

Clarke, L., \& Short, J. F., Jr. (1993). Social organization and risk: Some current controversies. Annual Review of Sociology, 19(1), 375-399.

Comerio, M. C. (1997). Housing issues after disasters. Journal of Contingencies and Crisis Management, 5(3), 166-178. https://doi.org/10.1111/1468-5973.00052.

Comerio, M. C. (1998). Disaster hits home: New policy for urban housing recovery. Oakland, CA: Univ of California Press.

Crisp, E. (2018, May 11). Legislation inspired by "Cajun Navy" to coordinate volunteer rescues nears final passage. The Advocate. Retrieved from https://www.theadvocate.com/baton_rouge/ news/politics/legislature/article_17e6a262-553111e8-8982-4f17c307d35f.html

Di Liberto, T. (2016, August 19). August 2016 extreme rain and floods along the Gulf Coast. National Oceanic \& Atmospheric Administration. Retrieved from https://www.climate.gov/ news-features/event-tracker/august-2016-extreme-rain-and-floods-along-gulf-coast

Di Liberto, T. (2017, September 18). Reviewing Hurricane Harvey's catastrophic rain and flooding. National Oceanic \& Atmospheric Administration. Retrieved from https://www.climate. gov/news-features/event-tracker/reviewing-hurricane-harveys-catastrophic-rain-and-flooding 
Dynes, R. R. (1974). Organized behavior in disaster. Columbus: Disaster Research Center, Ohio State University.

Dynes, R. R. (1983). Problems in emergency planning. Energy, 8(8), 633-660.

Elliott, J. R., \& Pais, J. (2010). When nature pushes back: Environmental impact and the spatial redistribution of socially vulnerable populations. Social Science Quarterly, 91(5), 1187. https:// doi.org/10.1111/j.1540-6237.2010.00727.x.

Federal Emergency Management Agency (FEMA) (2018). The National Flood Insurance Program. Retrieved from https://www.fema.gov/national-flood-insurance-program

Fernald, M. (2013). America's rental housing: Evolving markets and needs. Resource document. Cambridge, MA: Harvard University. http://www.jchs.harvard.edu/sites/jchs.harvard.edu/files/ jchs_americas_rental_housing_2013_10.pdf.

Finch, C., Emrich, C. T., \& Cutter, S. L. (2010). Disaster disparities and differential recovery in New Orleans. Population and Environment, 31(4).. https://www.jstor.org/stable/40587588), 179.

Forrest, T. R. (1978). Group emergence in disasters. In E. L. Quarantelli (Ed.), Disasters: theory and research (pp. 105-125). London: Sage.

Fothergill, A., \& Peek, L. (2004). Poverty and disasters in the United States: A review of recent sociological findings. Natural Hazards, 32(1), 89-110.

Freddie Mac (2017). Multifamily in focus: Rental affordability is worsening. Retrieved from http://www.freddiemac.com/multifamily/pdf/rental_affordability_worsening.pdf

Fritz, C. E. (1961). Disaster. In R. K. Merton \& R. A. Nisbet (Eds.), Contemporary social problems (pp. 651-694). New York: Harcourt, Brace, and World.

Fussell, E., \& Elliott, J. R. (2009). Introduction: Social organization of demographic responses to disaster: studying population-Environment interactions in the case of Hurricane Katrina. Organization \& Environment, 22(4), 379-394.

Fussell, E., \& Harris, E. (2014). Homeownership and housing displacement after Hurricane Katrina among low-income African-American mothers in New Orleans. Social Science Quarterly, 95(4), 1086-1100. https://doi.org/10.1111/ssqu.12114.

Fussell, E., Sastry, N., \& Vanlandingham, M. (2010). Race, socioeconomic status, and return migration to New Orleans after Hurricane Katrina. Population and Environment, 31(1-3), $20-42$.

Gallo, A. (2017a, June 17). Here's how Louisiana programs aim to rebuild thousands of flooded rentals, get owners "over the goal line." The Advocate. Retrieved from https://www.theadvocate.com/louisiana_flood_2016/article_8d7bead0-52c8-11e7-99ffcb4057db2000.html

Gallo, A. (2017b, October 24). \$150,000 grant to help Baton Rouge nonprofits build affordable rentals. The Advocate. Retrieved from https://www.theadvocate.com/baton_rouge/news/ article_0d7e448c-b8e3-11e7-9b2ac39c9eb20e23.html

GAO (2010). Disaster assistance: federal assistance for permanent housing primarily benefited homeowners; opportunities exist to better target rental housing needs (GAO 10-17). Washington, DC: U.S. Government Accountability Office.

Gotham, K. F. (2008). From 9/11 to 8/29: Post-disaster recovery and rebuilding in New York and New Orleans. Social Forces, 87(2), 1039. https://doi.org/10.1353/sof.0.0131.

Gotham, K. F., \& Greenberg, M. (2014). Crisis cities: Disaster and redevelopment in New York and New Orleans. New York: Oxford University Press.

Governor's Office of Homeland Security and Emergency Preparedness (GOHSEP) (2016). State of Louisiana Flooding August 2016 After Action Report/Improvement Plan. Baton Rouge, LA: GOHSEP.

Grueskin, C. (2017, December 17). New "piggyback" funding program targets rebuilding of mixed income rentals in flooded parishes. The Advocate. Retrieved from https://www.theadvocate. com/baton_rouge/news/article_e0faa738-e1c4-11e7-9f15132ff3a097b6.html

Grueskin, C. (2018a, February 5). A harsh reality: Program to house flooded renters living in FEMA trailers runs into lack of housing. The Advocate. Retrieved from https://www.theadvocate.com/baton_rouge/news/communities/livingston_tangipahoa/article_ccc573a-078b-11e8a69f-ef38c5208b9a.html 
Grueskin, C. (2018b, July 13). Restore Louisiana Task Force votes to give homeowners full reimbursement for flood repairs. The Advocate. Retrieved from https://www.theadvocate.com/ baton_rouge/news/article_7c944026-86c7-11e8-9cc843bb05594f02.html

Hamideh, S., \& Rongerude, J. (2018). Social vulnerability and participation in disaster recovery decisions: public housing in Galveston after Hurricane Ike. Natural Hazards, 93(3), 16291648. https://doi.org/10.1007/s11069-018-3371-3.

Hardy, S. (2017, July 26). Baton Rouge begins distribution of flood funds to help landlords and the homeless. The Advocate. Retrieved from https://www.theadvocate.com/baton_rouge/news/ article_e0d69642-7246-11e7-85e22381f48760df.html

Henrici, J. M., Helmuth, A. S., Fernandes, R. (2010). Mounting losses: Women and public housing after Hurricane Katrina (Publication No. D491). Retrieved from https://iwpr.org/wpcontent/ uploads/wpallimport/files/iwpr-export/publications/D491.pdf

Hilburn, G. (2017, August 29). Governor Edwards refuels Cajun Navy at border. News Star. Retrieved from https://www.thenewsstar.com/story/news/2017/08/29/gov-edwards-refuels-cajun-navyborder/613245001/

Hirayama, Y. (2000). Collapse and reconstruction: Housing recovery policy in Kobe after the Hanshin Great earthquake. Housing Studies, 15(1), 111-128. https://doi.org/10.1080/02673030082504.

Jones, T. L. (2017, February 12). Renters continue to struggle finding affordable rental units in Baton Rouge area after flood. The Advocate. Retrieved from https://www.theadvocate.com/ louisiana_flood_2016/article_6653239a-dce1-11e6-ad4a63b860ee4b50.html

Kendra, J. M., \& Wachtendorf, T. (2003). Elements of resilience after the World Trade Center disaster: Reconstituting New York City's emergency operations centre. Disasters, 27(1), 37-53. https://doi.org/10.1111/1467-7717.00218.

Kendra, J. M., \& Wachtendorf, T. (2016). American Dunkirk: The Waterborne Evacuation of Manhattan on 9/11. Philadelphia: Temple University Press.

Lee, J. Y., \& Zandt, S. V. (2018). Housing tenure and social vulnerability to disasters: A review of the evidence. Journal of Planning Literature, 34, 156. https://doi.org/10.1177/0885412218812080.

Louisiana Housing Corporation (2017). Baton Rouge Rebuilds. Retrieved from http://www.lhc. la.gov/page/baton-rouge-rebuilds

Louisiana Office of the Governor (2016). 2016 State of Louisiana historic flooding - Rebuilding and recovery update. Retrieved from http://gov.louisiana.gov/assets/docs/RestoreLA/ SupportingDocs/Meeting-11-18-16/LACongressional-Flood-Update-11-16-16.pdf

McCarthy, G., Van Zandt, S., \& Rohe, W. (2001). The economic benefits and costs of homeownership: A critical assessment of the research. (Working paper No. 01-02). Arlington: Research Institute for Housing America.

McCausland, P., Gosk, S., \& Helsel, P. (2017, August 27). Flooded Houston braces for more rain as Harvey rescues continue. NBC News. Retrieved from https://www.nbcnews.com/storyline/ hurricane-harvey/flooded-houston-braces-more-rain-rescues-continue-n796476

Meyer, M., Mitchell, B., \& Dombroski, S. (2018). Working with the Cajun Navy: Optimizing the use of volunteers in disaster response. National Science Foundation. Retrieved from https:// www.nsf.gov/discoveries/disc_summ.jsp?cntn_id=296509\&org=NSF\&from=news

Morrow, B. H. (1999). Identifying and mapping community vulnerability. Disasters, 23(1), 1. https://doi-org.ezproxy.library.tamu.edu/10.1111/1467-7717.00102.

Mukherji, A. (2015). From tenants to homeowners: Housing renters after disaster in Bhuj, India. Housing Studies, 30(7), 1135-1157. https://doi.org/10.1080/02673037.2015.1008423.

National Research Council. (2006). Facing hazards and disasters: Understanding human dimensions. Washington, DC: National Academies Press.

National Weather Service (NWS) (2017). NWS Directives (NWSI) 10-950 (Hydro definitions and general terminology). Retrieved from http://www.nws.noaa.gov/directives/sym/ pd01009050curr.pdf

National Weather Service (NWA) (2019). August 2016 Record Flood Summary Page. Retrieved from https://www.weather.gov/lix/August2016flood

Noji, E. K. (1997). The public health consequences of disasters. New York: Oxford University Press. 
Pais, J., \& Elliott, J. (2008). Place as recovery machines: Vulnerability and neighborhood change after major hurricanes. Social Forces, 86(4), 1415-1452.

Peacock, W. G., Morrow, B. H., \& Gladwin, H. (Eds.). (1997). Hurricane Andrew: Ethnicity, gender and the sociology of disasters. New York: Routledge.

Peacock, W. G., Van Zandt, S., Zhang, Y., \& Highfield, W. E. (2014). Inequities in long-term housing recovery after disasters. Journal of the American Planning Association, 80(4), 356-371.

Peacock, W. G., Dash, N., Zhang, Y., \& Van Zandt, S. (2018). Post-disaster sheltering, temporary housing and permanent housing recovery. In Handbook of disaster research (pp. 569-594). Springer.

Perry, R. W., \& Lindell, M. K. (2003). Preparedness for emergency response: Guidelines for the emergency planning process. Disasters, 27(4), 336-350.

Phillips, B. D., Thomas, D. S. K., Fothergill, A., \& Blinn-Pike, L. (Eds.). (2010). Social vulnerability to disasters. Boca Raton: CRC Press.

Phillips, B. D., \& Fordham, M. (2010). Introduction. In B. D. Phillips, D. S. K. Thomas, A. Fothergill, \& L. Blinn-Pike (Eds.), Social Vulnerability to Disasters (pp. 1-26). Boca Raton, FL: CRC Press.

Raja, T. (2017, August 27). A makeshift navy struggles to respond to Hurricane Harvey. The New Yorker. Retrieved from https://www.newyorker.com/news/news-desk/ houston-a-makeshift-navy-struggles-to-respond-to-hurricane-harvey

Reidmiller, D. R., Avery, C. W., Easterling, D. R., Kunkel, K. E., Lewis, K. L. M., Maycock, T. K., \& Stewart, B. C. (Eds.) (2017). Impacts, risks, and adaptation in the United States: fourth national climate assessment, Vol. 2. US Global Change Research Program. doi:https:// doi.org/10.7930/NCA4.2018.

Rhoden, R. (2016, August 19). Where they died: Interactive map shows Louisiana flooding victims. NOLA.com/The Times-Picayune. Retrieved from https://www.nola.com/weather/index. ssf/2016/08/la_flood_victims_black_and_whi.html

Rohe, W. M. (2017). Tackling the housing affordability crisis. Housing Policy Debate, 27(3), 490494. https://doi.org/10.1080/10511482.2017.1298214.

Rubin, C. B. (2009). Long term recovery from disasters - The neglected component of emergency management. Journal of Homeland Security and Emergency Management, 6(1).

Schneider, S. (1992). Governmental response to disasters: The conflict between bureaucratic procedures and emergent norms. Public Administration Review, 52(2), 135-145. https://www. jstor.org/stable/976467.

Scott, M. (2016, August 16). National media fiddle as Louisiana drowns. NOLA.com/The Times Picayune. Retrieved from https://www.nola.com/weather/index.ssf/2016/08/national_media_ louisiana_flood.html

Siegel, G. B. (1985). Human resource development for emergency management. Public Administration Review, 45, 107-117.

Steffen, S. L., \& Fothergill, A. (2009). 9/11 volunteerism: A pathway to personal healing and community engagement. The Social Science Journal, 46(1), 29-46.

Terrell, D. (2016). The economic impact of the August 2016 Floods on the State of Louisiana. Louisiana Economic Development. Retrieved from http:/gov.louisiana.gov/assets/docs/ RestoreLA/SupportingDocs/Meeting-9-28-16/2016-August-Flood-Economic-ImpactReport_09-01-16.pdf

Thomas, D. S. K., Phillips, B., Lovekamp, W. E., \& Fothergill, A. (Eds.). (2013). Social vulnerability to disasters (2nd ed.). Boca Raton: CRC Press.

Tierney, K. J., Lindell, M. K., \& Perry, R. W. (2001). Facing the unexpected: Disaster preparedness and response in the United States. Washington, DC: Joseph Henry Press.

Tulane School of Architecture (2007). The "Big Four" public housing projects are demolished post-Katrina. New Orleans Preservation Timeline Project. Retrieved from http://architecture. tulane.edu/preservation-project/timeline-entry/1427

U.S. Department of Housing \& Urban Development (HUD) (2018). Affordable Housing. Retrieved from https://www.hud.gov/program_offices/comm_planning/affordablehousing/ 
Van Zandt, S., Peacock, W. G., Henry, D. W., Grover, H., Highfield, W. E., \& Brody, S. D. (2012). Mapping social vulnerability to enhance housing and neighborhood resilience. Housing Policy Debate, 22(1), 29-55.

Walters, E. (2018, April 16). "It's our form of apartheid": How Galveston stalled public housing reconstruction in the 10 years after Ike. The Texas Tribune. Retrieved from https://www.texastribune.org/2018/04/16/galveston-public-affordable-housing-hurricane-ike/

Weil, H. J. (2009). Finding housing: Discrimination and exploitation of Latinos in the post Katrina rental market. Organization \& Environment, 22(4), 491-502. https://doi. org/10.1177/1086026609347194.

Yan, H. \& Flores, R. (2016, August 19). Louisiana flood: Worst US disaster since Hurricane Sandy, Red Cross says. CNN. Retrieved from https://www.cnn.com/2016/08/18/us/louisianaflooding/ index.html

Zhang, Y., \& Peacock, W. G. (2009). Planning for housing recovery? Lessons learned from Hurricane Andrew. Journal of the American Planning Association, 76(1), 5-24. https://doi. org/10.1080/01944360903294556.

Open Access This chapter is licensed under the terms of the Creative Commons Attribution 4.0 International License (http://creativecommons.org/licenses/by/4.0/), which permits use, sharing, adaptation, distribution and reproduction in any medium or format, as long as you give appropriate credit to the original author(s) and the source, provide a link to the Creative Commons license and indicate if changes were made.

The images or other third party material in this chapter are included in the chapter's Creative Commons license, unless indicated otherwise in a credit line to the material. If material is not included in the chapter's Creative Commons license and your intended use is not permitted by statutory regulation or exceeds the permitted use, you will need to obtain permission directly from the copyright holder. 